\title{
Peran Ganda (Bekerja Sekaligus Ibu Rumah Tangga) Perempuan Muslimah Dalam Perspektif Struktural Fungsional
}

\author{
Suharnanik \\ Universitas Wijaya Kusuma Surabaya \\ nanik_fisip@uwks.ac.id
}

\begin{abstract}
The dual role of Muslim women in functional structural construction gets its supportive theories. It may sound classic, but such perspective is sufficiently supportive towards the construction of women and such phenomenon is happening in the society today. Women who work in the conception of Islam are considered supporting the family construction in adaptive and integrative functions. Self-control in working women in demanding their rights to be a superior in the household is controlled by religious values, so that women are willing to be number two where men are still the family leaders. This study describes the data descriptively with a qualitative approach, accompanied by several references in sharpening the writing analysis. The results of this study indicate that working Muslim women are more cooperative in carrying out roles in the household as feminine humans by showing their expressive character, while men are more masculine with roles that tend to be instrumental. Women with a more expressive character, supported by Islamic religious value system that teaches women as a makmum (someone who joins in an Islamic prayer) for men in the family, tend to take a good care of the family with sincerity and responsibility.
\end{abstract}

Keywords: Women, Muslimah, Working Women, Women's dual roles in the family.

\begin{abstract}
Abstrak
Peran ganda wanita muslimah dalam konstruksi struktural fungsional mendapatkan teori pendukungnya. Mungkin terdengar klasik, namun cara pandang tersebut cukup mendukung terhadap konstruksi perempuan dan fenomena yang terjadi di masyarakat saat ini. Perempuan yang bekerja dalam konsepsi Islam dianggap mendukung konstruksi keluarga dalam fungsi adaptif dan integratif. Pengendalian diri pada perempuan pekerja dalam menuntut haknya untuk menjadi atasan dalam rumah tangga dikendalikan oleh nilai-nilai agama, sehingga perempuan rela menjadi nomor dua dimana laki-laki masih menjadi pemimpin keluarga. Penelitian ini mendeskripsikan data secara deskriptif dengan pendekatan kualitatif, disertai dengan beberapa referensi dalam mempertajam analisis penulisan. Hasil penelitian ini menunjukkan bahwa wanita muslimah yang bekerja lebih kooperatif dalam menjalankan peran dalam rumah tangga sebagai manusia feminin dengan menunjukkan karakter ekspresifnya, sedangkan pria lebih maskulin dengan peran yang cenderung instrumental. Perempuan dengan karakter yang lebih ekspresif,
\end{abstract}


didukung oleh sistem nilai agama Islam yang mengajarkan perempuan sebagai makmum bagi laki-laki dalam keluarga, cenderung mengurus keluarga dengan ikhlas dan tanggung jawab.

Kata kunci: Perempuan, Muslimah, Perempuan Bekerja, Peran ganda perempuan dalam keluarga.

\section{Pendahuluan}

Perempuan masuk ruang sistem keluarga menggunakan beragam adat dan nilai, seperti yang disampaikan oleh Pauline, dalam proses pernikahan dapat ditemukan citra budaya perempuan. ${ }^{1}$ Pengalaman ritual pernikahan dengan beragam nilai dan norma yang dilaluinya mempengaruhi komitmennya dalam menghargai sebuah sistem keluarga. Namun karena kultur dan nilai pula perempuan menjadi 'silent person' ketika menghadapi kekerasan dalam rumah tangganya. Dalam Sever, perempuan mengalami kekerasan dalam sistem keluarga patriakhi. ${ }^{2}$ Beberapa kasus yang dialami perempuan terjadi dalam struktur yang ketat, seperti dalam telaahan Astutik dan Laksono, terdapat beberapa kekerasan yang terjadi pada perempuan diantaranya menyebabkan kekerasan fisik, pelecehan psikologis, penyalahgunaan ekonomi, dan kekerasan sosial cemburu adalah 69,76\%, memberontak pasangan mereka $16,27 \%$, pengaruh teman adalah $9,30 \%$, dan sakit hati atau dendam adalah $4,65 \% .{ }^{3}$ Lembaga otoritas juga mampu mengkonstruksi perempuan yang bersedia menikah usia dini, keterlibatan nilai dan pengetahuan yang masih kurang sempurna memberdayakannya. ${ }^{4}$ Berbagai nilia-nilai teologis dan kultural menjadi hal yang perlu dipertanyakan fungsinya seiring kemajuan ilmu pengetahuan dan teknologi dalam membangun kesadaran. ${ }^{5}$ Perempuan dalam mengembangkan perilaku hidupnya mencari sosok figur, sebagai prose adaptasi nilai. ${ }^{6}$ Perempuan memberikan kontribusi dalam menjaga fungsi keluarga yang menikah dengan kultur yang berbeda, perempuan yang lebih taat dalam beragama

\footnotetext{
${ }^{1}$ Pauline Kolenda, "Woman as Tribute, Woman as Flower: Images of 'Woman' in Weddings in North and South India," American Ethnologist 11, no. 1 (1984): 98-117.

${ }^{2}$ Aysan Sev'er and Gökçeçiçek Yurdakul, "Culture of Honor, Culture of Change: A Feminist Analysis of Honor Killings in Rural Turkey," Violence Against Woman 7, no. 9 (September 30, 2001): 964-998, http://journals.sagepub.com/doi/10.1177/10778010122182866.

${ }^{3}$ Juli Astutik and Sugeng P Laksono, "Kekerasan Gender Dalam Berpacaran Di Kalangan Mahasiswa (Studi Kasus Di Malang) Gender Abuse on Dating of University Students (Case Study in Malang)," Jurnal Perempuan dan Anak 1, no. 1 (2015): 1-22.

${ }^{4}$ Inayah Rohmaniyah, "Kontruksi Seksualitas Dan Relasi Kuasa Dalam Praktik Diskursif Pernikahan Dini," Musãwa Jurnal Studi Gender dan Islam 16, no. 1 (2018): 33.

${ }^{5}$ Siti Zubaedah, "Mengurai Problematika Gender Dan Agama," JURNAL STUDI GENDER \& ANAK (2010).

${ }^{6}$ Abima Narasatriangga, . Purwadi, and I Nyoman Dhana, "Dominasi Kultural Figur Bunda Maria Dalam Ritual Semana Santa Pada Masyarakat Larantuka, Flores Timur," Humanis (2018): 935.
} 
Peran Ganda (Bekerja Sekaligus Ibu Rumah Tangga) Perempuan Muslimah...

mampu membuat sebuah keluarga yang jauh dari perceraian. ${ }^{7}$

Fungsi adaptif yang ditawarkan dalam teori struktural fungsional apakah mampu menjawab berbagai permasalahan yang terjadi pada perempuan. Tentunya membuat pertanyaan yang menduga-duga seakan konsep ini sudah sangat tua untuk digunakan dalam membaca realitas fenomena saat ini yang sedang terjadi. Perempuan yang bekerja masih mampu berperan ganda dalam konstruksi sistem keluarga yang ketat membutuhkan komitmen yang sangat tinggi, sehingga membutuhkan konsep teori yang tepat dalam melakukan pendekatannya.

Dalam mengelaborasi sebuah sistem yang terdiri dari beberapa elemen dan fungsi, menormalisasi beberapa nilai menjadi sebuah kesatuan yang utuh dan berkesinampungan tentunya teringat sebuah konsep teori struktural fungsional. Oleh sebab itu, pendekatan sistem ini digunakan oleh peneliti dalam membedah fenomena yang saat ini kerap terjadi pada perempuan yang bekerja, namun masih tetap memiliki peran ganda yaitu menjadi ibu rumah tangga. Tentunya dengan pengamatan sosial peneliti, mengobservasi perempuan yang bekerja tersebut lebih harmoni, lebih tidak ada konflik dan lebih terkoordinasi dengan baik terjadi pada perempuan muslim. Lalu bagaimana proses perjalanan elaborasi perempuan tersebut sehingga mampu menerimanya, untuk itulah penelitian ini menarik hadir untuk menyajikan fenomena ini dengan lebih detailnya.

\section{Metode}

Metode penelitian ini menggunakan penelitian kualitatif, ${ }^{8}$ diantaranya memahami perempuan pekerja sebagai subyek peneliti, melakukan penyelidikan efek dari konteks secara spesifik, menjelaskan proses menjadi makna dan bagaimana perempuan bekerja mampu beradaptasi dengan fungsi yang dijalaninya. Penelitian ini melibatkan perempuan, tentunya mengandung misi membela perempuan. Sebagaimana metode yang digunakan oleh Payne melibatkan perempuan. ${ }^{9}$ Dalam penelitian kualitatif, meskipun hanya bersifat memaparkan, namun kaidah-kaidah yang dibangun juga sama ketatnya dengan penelitian kuantitatif, termasuk penelitian yang menggunakan pendekatan feminis. ${ }^{10}$ Dengan metode wawancara, pengamatan langsung serta studi referensi terhadap perempuan bekerja bagaimana mengadaptasikannya pada sistem keluarga. Data yang diperoleh, kemudian dianalisa dengan perspektif teori modern struktural fungsional.

\footnotetext{
${ }^{7}$ Bernard Lazerwitz, "Jewish-Christian Marriages and Conversions, 1971 and 1990," Sociology of Religion 56, no. 4 (1995): 433.

8 Joseph A. Maxwell and L. Earle Reybold, "Qualitative Research," in International Encyclopedia of the Social \& Behavioral Sciences: Second Edition, 2015.

${ }^{9}$ Geoff Payne and Judy Payne, Key Concepts in Social Research (Trowbridge,Wilture: The Cromwell Press Ltd, 2004).

${ }^{10}$ Carol Grbich, "New Approaches in Social Research," New Approaches in Social Research (2011).
} 
Penelitian mempunyai metode yang lebih khas dalam melihat kompleknya kehidupan perempuan dalam sebuah sistem yang ketat seperti sistem keluaga. Hal inilah yang membuat penelitian harus menggunakan pendekatan kualitatif penelitian sosial, sebagaimana dalam Marvasti, yang menyebut bahwa pendekatan penelitian sosial lebih menekankan pada pengungkapan yang terjadi dalam kehidupan manusia pada umumnya. Kejadian sehari-hari berada disekitar peneliti dapat berupa pengalaman perempuan bekerja sekaligus menjadi bagian dari sistem keluarga yang utuh. Melalui pengamatan yang sistematis menjadi bagian dari tindkan penelitian sosial dengan menganalisa sumber referensi yang tepat dalam melihat fenomena perempuan bekerja. ${ }^{11}$

\section{Konsep Dasar Teori}

Konsep dasar teori yang dijelaskan Paloma adalah mengacu pada konsep tindakan sosial yang rasional, suatu konsep yang semula merupakan sumbangan teoritis Max Weber. ${ }^{12}$ Bahkan dalam penjelasan lebih rinci, merupakan kumpulan dari beberapa pemikiran dari seperti Durkheim, Pareto, Weber dan Freud yang melebur menjadi satu dalam sebuah teori Fungsionalisme Struktural dan sasaran dari teori ini adalah struktur sosial dan institusi masyarakat berskala luas, antar hubungannya, dan pengaruhnya terhadap aktor. Menurut Kingsley Davis dan Wilbert yang menjelaskan bahwa penempatan sosial dalam stratifikasi sosial merupakan fenomena universal yang menyebabkan masalah dengan tiga alasan mendasar. Dalam Ritzer membagi dalam beberapa posisi diantaranya: Pertama, posisi tertentu lebih menyenangkan untuk diduduki ketimbang posisi yang lain. Kedua, posisi tertentu lebih penting untuk menjaga kelangsungan hidup masyarakat ketimbang posisi yang lain. Ketiga, posisi-posisi sosial yang berbeda memerlukan bakat dan kemampuan yang berbeda pula. ${ }^{13}$ Pemilihan dan penempatan posisi sosial ini yang akan menyebabkan sistem sosial mengalami gangguan apabila terdapat ketidakseimbangan antara apa yang didapatkan dengan apa yang dilakukan. Setiap individu memberikan kontribusi dalam menyusun sebuah sistem sosial sehingga kemampuan tersebut akan dianggap penting dan dilakukan dengan penuh tanggung jawab apabila terpenuhi setiap faktor yang mendukungnya. Meskipun tidak semuanya dapat dilakukan dengan menggunakan pendekatan yang sama karena setiap individu memiliki karakter yang sangat berbeda antara satu dengan yang lainnya.

\footnotetext{
${ }^{11}$ Amir B Marvasti, Qualitative Research in Sociology, ed. David Silverman (London • Thousand Oaks • New Delh: SAGE Publications Ltd., 2004).

${ }^{12}$ Margaret. M Poloma, Sosiologi Kontemporer (Jakarta: Raja Grafindo Persada, 2010).

${ }^{13}$ George Ritzer and Douglas J Goodman, Teori Sosiologi Modern (Jakarta: Prenada, 2005).
} 


\section{Teori Struktural Fungsional}

Parsons membahas teori struktural fungsional dalam Ritzer, untuk semua sistem tindakan yang terkenal dengan skema AGIL, keempat emparatif ini secara bersama-sama melakukan fungsinya agar dapat bertahan atau survive. Adapun keempat fungsi tersebut adalah sebagai berikut:

1. Adaption (Adaptasi) : sebuah sistem harus menanggulangi situasi eksternal yang gawat. Sistem harus menyesuaikan diri dengan lingkungan dan menyesuaikan lingkungan itu dengan kebutuhannya.

2. Goal attainment (Pencapaian tujuan): sebuah sistem harus mendefinisikan dan mencapai tujuan utamanya.

3. Integration (Integrasi): sebuah sistem harus mengatur antarhubungan bagianbagian yang menjadi komponennya. Sistem juga harus mengelola antarhubungan ketiga fungsi penting lainnya (A,G, L).

4. Latency (Latensi atau pemeliharaan pola): sebuah sistem harus melengkapi, memelihara dan memperbaiki, baik motivasi individual maupun pola-pola kultural yang menciptakan dn menopang motivasi.

Parson menjelaskan adanya tingkat integrasi yang terjadi melalui dua cara: Pertama, masing-masing tingkat yang lebih rendah menyediakan kondisi atau kekuatan yang diperlukan untuk tingkat yang lebih tinggi. Kedua, tingkat yang lebih tinggi mengendalikan tingkat yang berada di bawahnya. ${ }^{14}$ Parson menemukan jawaban problem didalam fungsionalisme struktural dengan asumsi sebagai berikut:

1. Sistem memiliki property keteraturan dan bagian-bagian yang saling tergantung.

2. Sistem cenderung bergerak terus, mempertahankan keteraturan mempertahankan diri dalam keseimbangan.

3. Sistem mungkin statis atau bergerak dalam proses perubahan yang teratur.

4. Sifat dasar bagian suatu sistem berpengaruh terhadap bentuk bagian-bagian lain.

5. Sistem memelihara batas-batas dengan lingkungannya.

6. Alokasi dan integrasi merupakan dua proses fundamental yang diperlukan untuk memelihara keseimbangan sistem.

7. Sistem cenderung menuju remote pemeliharaan keseimbangan diri yang meliputi pemeliharaan batas dan pemeliharaan hubungan antara bagian-bagian dengan keseluruhan sistem, mengendalikan lingkungan yang berbeda-beda dan mengendalikan kecendrungan untuk merubah sistem dari dalam.

Meski Parson berkomitmen untuk melihat sistem sosial sebagai sebuah interaksi, namun ia tak menggunakan interaksi sebagai unit fundamental dalam studi sistem sosial. Status dan peran dipergunakan sebagai unit analisa dasar dari sistem sosial, tapi cara melihatnya tidak hanya sekedar sebagai kumpulan beberapa status dan peran. Selain itu Parson juga melihat sistem sosial dalam bentuk

${ }^{14}$ Ibid.

Suharnanik 59 
kolektivitas, norma dan nilai. Ia menjelaskan sejumlah persyaratan fungsional dari sistem sosial. Pertama, sistem sosial harus terstruktur (ditata) sedemikian rupa sehingga bisa beroperasi dalam hubungan yang harmonis dengan sistem lainnya. Kedua, untuk menjaga kelangsungan hidupnya, sistem sosial harus mendapat dukungan yang diperlukan dari sistem yang lain. Ketiga, sistem sosial harus mampu memenuhi kebutuhan para aktornya dalam proporsi yang signifikan. Keempat, sistem harus mampu melahirkan partisipasi yang memadai dari para anggotanya. Kelima, sistem sosial harus mampu mengendalikan perilaku yang berpotensi mengganggu. Keenam, bila konflik akan menimbulkan kekacauan, itu harus dikendalikan. Ketujuh, untuk kelangsungan hidupnya, sistem sosial memerlukan bahasa. ${ }^{15}$

\section{Kritik Teori Parsons}

Fenomena yang terjadi dalam masyarakat, tidak selalu harus diselesaikan dengan cara adaptasi sistem. Sebagaimana yang telah dikritik dalam Tauleka, mengkaji tentang bagaimana fenomena sosial dapat dikaji dengan pendekatan konflik. ${ }^{16}$ Hal tersebut juga bagian dari kritik terhadap teori fungsional. Seperti halnya kritik yang digambarkan oleh Kalr Marx, Lewis A. Coser, Ralf Dahrendorf, Merton dan lain-lain yang bekerja dalam fungsionalime struktural tidak membawa perubahan besar dalam fungsionalisme struktural sebab mereka tetap mempertahannya. ${ }^{17}$ Parson melihat bahwa klasifikasi bukanlah satu-satunya hal yang dipikirkan oleh Parsons, oleh karena dia juga mengembangkan prioritas pengembangan sistem konsep-konsep terhadap sistem preposisi. ${ }^{18}$ Sehingga apabila terjadi kejadian-kejadian yang menyebabkan penyimpangan terhadap teori ini sebenarnya telah diperkirakan oleh Parson sendiri karena fenomena kejadian terhadap relaitas sosial selalu mengalami perubahan hingga sulit untuk diprediksi.

Konsep-konsep dalam teori tidak boleh dimasukkan ke dalam proposisiproposisi secara prematur. ${ }^{19}$ Seringkali kejadian-kejadian terhadap realitas sosial dapat terjadi penyimpangan terhadap teori fungsionalime struktural meskipun setiap elemen dalam keempat emparatif terpenuhi namun keberlangsungan sistem sosial tersebut tidak terjamin dan bahkan terdapat pula fenomena tidak terpenuhinya keempat emparatif sebagaimana dalam teorinya Parson namun keberlangsungan dari sistem sosial tersebut terjaga dengan baik dan diakui keberadaannya dalam masyarakat. Bagi feminis struktural fungsional, pembagian peran perempuan dan laki-laki merupakan bagian dari menjaga keteraturan sistem tersebut. Bisa jadi,

\footnotetext{
${ }^{15}$ Ibid.

${ }^{16}$ M. Wahid Nur Tualeka, "Teori Konflik Sosiologi Klasik Dan Modern,” Al-Hikmah (2017).

${ }^{17}$ Barry Ritzer, George and Smart, Hand Book Teori Sosial (Bandung: Nusa Media, 2014).

${ }^{18}$ Soerjono Soekanto, Tujuh Tokoh Sosiologi (Jakarta: Raja Grafindo Persada, 2011).

${ }^{19}$ Ibid.
}

60 Suharnanik 
dalam pengamatan diluar bidang kajian sosiologi hubungan laki-laki dan perempuan dalam sistem sosial adalah hal yang alami dan nampak biasa, dimana laki-laki memiiki status yang lebih tinggi karena bekerja sementara perempuan nomor dua karena tidak bekerja, lalu bagaimana jika perempuan itu bekerja? Apakah akan diperlakukan sama nomor duanya ataukah ada perubahan status atas peran yang didapat dalam wilayah publik tersebut lalu bagaimana kaitannya dengan sistem keluarga.

\section{Pembahasan}

Kajian perempuan dalam sosiologi erat kaitannya dengan kajian gender, mendefinisikan perempuan dalam pandangan masyarakat yang struktural fungsional. Keluarga bagian dari sistem sosial yang cenderung adaptif, bagaimanapun keluaga dibangun untuk menjadi utuh terbangun atas beberapa pranata sosial yang mengikat, seperti norma dan nilai. Dalam struktural fungsional, perempuan dipengaruhi oleh struktur sosial dimana institusi masyarakatnya berada. Perempuan yang bekerja jika dalam struktur masyarakat Bali merupakan wilayah kerja yang telah diatur dalam normanya, sedangkan laki-laki lebih banyak bertugas dalam norma agama sebagai penjaga kuil dan perangkat struktur pemerintahan serta ritual keagamaan. Sebenarnya dalam konsep tindakan sosial yang rasional, sebagaimana Max Weber katakan bahwa sebuah tindakan setiap individu yang dilakukan akan berdampak pada tindakan bersama dalam menjamin konsepsi institusional ini terbentuk. Secara rasional sengaja diarahkan konsep tindakan yang disepakati bersama demi sebuah kestabilan dan keberlanjutan.

Merujuk pada penjelasnnya Kingsley Davis dan Wilbert, perempuan dalam struktural fungsional memiliki cakupan yang sangat luas, menjaga keterhubungan antar pranata yang dibentuk sehingga perannya tidak dapat digantikan dengan gender lain, ketika sebuah sistem membutuhkan kesinambangannya. Penempatan perempuan dalam stratifikasi sosial merupakan fenomena biasa yang terjadi hampir disemua negara, dalam konsep ini dapat dijadikan sebuah konsep universal dikarena: posisi perempuan dalam strafikasi sosial tertentu harus dibuat menguntungkan dan menyenangkan perempuan tanpa paksaan sehingga perempuan bersedia menduduki posisi stratifikasi tersebut ketimbang posisi tempat yang lainnya.

Perempuan menempati posisi tertentu dalam sebuah sistem sosial lebih penting untuk menjaga kelangsungan hidup masyarakat. Ini terjadi dalam sebuah sistem terdapat lapisan posisi yang harus diisi dengan orang-orang yang memiliki peranan utama yang apabila digantikan dengan gender lain maka mengancam keberlangsungan sistem tersebut. Perempuan bekerja tetap ditempatkan dalam posisi rumah tangga sebagai ibu yang paling utama menjaga dan merawat rumah karena posisi tersbut penting dalam menjaga kestabilan keluarga. Peran ganda harus 
dimiliki seorang perempuan yang bekerja, karena posisi penting tersebut jika digantikan oleh laki-laki maka kestabilan dalam keluarga akan terganggu.

Perempuan bekerja dalam struktural fungsional, tetap bertanggungjawab dalam urusan domestik kerumahtanggaan. Hal tersebut terjadi karena bakat dan kemampuan perempuan yang berbeda dengan laki-laki. Perempuan dikonstruksi sejak lahir kedua oleh sistem nilai dan agama menjadi manusia yang memiliki sifat feminim yang lebih bersifat ekspresif dari pada laki-laki yang bakatnya sejak lahir cenderung dikontruksikan lebih maskulin dengan peran instrumentalnya. Hal yang berbeda ini, dalam pandangannya struktural fungsional jangan di bolak-balikkan, asumsi resiko yang didapat lebih berakibat pada keretakan sebuah sistem keluarga.

Sebuah sistem membutuhkan karakter yang berbeda dalam menjalankan fungsinya, perempuan menempati karakter yang dibutuhkan dalam sistem keluarga. Kontribusi yang diberikan perempuan dengan tanggung jawab menjadi penting dalam memenuhi pendukung faktor yang diperlukan. Laki-laki dan perempuan memiliki karakter yang berbeda, oleh sebab itu dalam menempatkan posisi dan perannya membutuhkan kesepakatan dan pendekatan yang berbeda pula. Yang paling utama adalah bagaimana peran tersebut dapat dijalani dengan tanggungjawab yang utuh serta tidak ada peran yang terabaikan begitu saja.

Parson mengungkapkan fenomena sosial dengan teorinya struktural fungsional dengan skema yang cukup fenomenal yaitu AGIL, lalu bagaimana perempuan bekerja dapat menempati fungsi emparatif tersebut:

1. Adaption (adaptasi) ; sebuah sistem membutuhkan peran perempuan dalam menanggulangi situasi eksternal yang berpotensi merusak keberlangsungaan sistem keluarga. Selain itu keluarga mampu menyesuaikan dengan lingkungan dan kebutuhan dalam merawat keberlangsungannya. Beberapa material dibutuhkan dalam menunjang opersioanalnya, perempuan bekerja sebagai upaya menanggulangi agar terhindar dari kekurangan kemampuan keluarga dalam memenuhi kebutuhannya. Sementara peran lainnya yang bersifat domestik jika dapat digantikan dengan individu yang lainnya maka kondisi keuarga akan tetap sustainable.

2. Perempuan muslimah yang bekerja menjaga komitmennya dan mampu bekerjasama secara solid dalam menggapai tujuan dalam berkeluarga. Tujuan dalam keluarga Islam yaitu tercapainya keluarga yang "Sakinah Mawaddah Warrohmah", tentunya sangat mempengaruhi perempuan dalam membangun tujuan dalam berkeluarga. Kolaborasi yang dibangun dengan laki-laki mengutamakan kaidah-kaidah dalam tatanan nilai yang dipercayanya. Fungsi Goal attainment lebih dapat dicapai jika keluaga dibangun dengan perempuan muslimah, meskipun perempuan bekerja tidak menjadikannya luntur mencapai tujuannya. Ada kompromi-kompromi yang dilakukan perempuan dalam pencapaian tujuan keluarga dapat dijaga, bisa juga melakukan jenis-jenis 
Peran Ganda (Bekerja Sekaligus Ibu Rumah Tangga) Perempuan Muslimah...

pekerjaan yang lebih fleksibel dengan tanggung jawabnya sebagai perempuan rumah tangga.

3. Fungsi keluarga dalam mengatur perempuan bekerja lebih mudah dilakukan pada perempuan muslimah. Semakin taat ritual keagamaannya, dapat lebih mudah diatur menjadi bagian-bagian keluarga sehingga kompenen sistem keluarga terpelihara secara utuh dan berfungsi secara baik. Keluarga dengan bagian perempuan muslimah yang bekerja lebih mudah diatur untuk diajak berkoordinasi dalam mengelola fungsi lainnya seperti fungsi Adaption, Goal Attainment serta Latensi. Bagi perempuan yang bekerja ketika ditanya untuk apa anda bekerja, maka jawabnya adalah "saya bekerja untuk membahagiakan anak dan suami saya", sementara mengapa anda melakukan ini, maka jawabannya adalah "saya mengabdi pada keluarga, karena saya ingin menjadi hamba yang sholeha". Begitulah sekiranya ilustrasi dari petikan jawaban dari perempuan muslimah yang bekerja dalaam membangun kerumahtangaannya.

4. Dalam sebuah keluarga harus saling melengkapi, latency menjadi unsur yang penting dalam menjaganya. Fungsi melengkapi, memelihara dan memperbaiki antar individu dalam anggota keluarga menjadi tolak ukur keberlangsungan sebuah keluarga. Keluarga harus dilengkapi dengan kepala rumah tangga yang mencari nafkah sebagai biaya materiil sementara perempuan boleh membantunya bekerja tanpa mengabaikan tugasnya sebagai ibu rumah tangga dengan memastikan semua anggota keluarga terawatt dengan baik untuk menjalani kehidupannya masing-masing. Anak-anak dalam keluarga yang harmonis lebih termotivasi dalam menjalani pendidikan dan karir masa depannya. Mampu menekuni hobbynya yang membuatnya sukses dimasa depannya.

Bagi pandangan struktural fungsional, sistem keluarga dalam menjaga integrasi atau keutuhan keluarganya memiliki tingkat integrasi yang terbagi melalui dua cara, yaitu: pertama, masing-masing anggota keluarga harus bersedia membagi tingkatan antara yang lebih tinggi dengan yang lebih rendah, dimana tingkatan yang lebih rendah menyediakan kondisi atau kekuatan yang diperlukan untuk tingkatan yang lebih tinggi. Perempuan bersedia menyerahkan pucuk pimpinan keluarga pada laki-laki, dimana dalam buku akad nikah bagi keluarga muslim sudah diatur yang menyatakan bahwa suami adalah pemimpin keluarga, sementara istri harus mematuhi apa kata suami. Kedua, tingkatan terbagi atas tinggi dan rendah. Jika kekuatan ditujukan pada suami, maka kesepakatan harus dibangun dan semua anggota harus menjalankan kekuasaan dan kendali atas tingkatan tinggi tersebut.

Struktural fungsional, mampu mempertahankan keberadaan sistem keluarga dengan asumsi sebagai berikut:

1. Sistem keluarga dibangun atas dasar nilai, sebuah property keteraturan dengan bagian-bagiannya yang saling tergantung. Nilai yang bangun keluarga muslim 
mengatur perempuan yang bekerja agar tetap tunduk dan patuh, sistem keteraturan ini bekerja secara alami dengan kondisi budaya yang mendukung. Nilai Islam dalam balutan budaya islami mendorong perilaku perempuan bekerja memiliki karakter yang lebih adaptif dalam mengadopsi peraturan keluarga.

2. Sistem keluarga mendorong bergerak secara dinamis, mengikuti nilai-nilai yang tertatur guna mempertahankan diri dalam keseimbangan.

3. Keluarga yang menahan diri dari pengaruh luar cenderung statis, namun kadangkala tetap terbuka dalam proses perubahan yang teratur.

4. Setiap bagian dari unsur pembentuk dalam sistem keluarga saling berpengaruh terhadap bentuk bagian-bagian lainnya, pemimpin dalam keluarga mempengaruhi anggota keluarga yang dipimpin. Anak-anaknya akan terdidik secara teratur dan disiplin bertanggungjawab jika dibangun atas dasar perilaku pemimpin keluarga yang berbiasa disiplin dan tanggungjawab.

5. Dengan menganut sistem keluarga, setiap individu secara teratur akan terpelihara dengan batas-batas nilai dan norma yang dibangun dalam keluarga. Batas-batas nilai dan norma yang ditekankan menjaganya terhadap pengaruh dari lingkungan luar.

6. Dalam memelihara keseimbangan sistem keluarga memerlukan alokasi pemikiran, waktu dan tenaga guna terciptanya keutuhan sistem keluarga. Alokasi materi guna mencipatakan keutuhan bersama, dapat berupa kebersamaan saat berekreasi bersama seluruh anggota keluarga untuk mempererat keutuhan keluarga.

7. Keluarga membina para anggotanya mengarah pada keseimbangan sistem yang meliputi pemeliharaan batas dan pemeliharaan hubungan antara bagian dengan keseluruhan sistem, memfiter beragam pengaruh luar yang merusak sistem keluarga dengan propaganda agama dan nilai seperti "rumahmu adalah surgamu". "just feel like home", "home sweet home", menjadi jargon pengendalian sistem keluarga dari keretakan.

Komitmen teori struktural fungsional dalam membangun dan mempertahan sistem keluarga masih dalam tingkatan pengelolaan sisten sosial sebagai sebuah interaksi, bukan sebagai unit fundamental dan sebuah sistem sosial. Status dan peran perempuan muslimah yang bekerja harus mampu mensinergikan beberapa kumpulan nilai-nilai dan norma yang dibangun dan didapatkan dalam agamanya, ruang kerjanya serta norma keluarganya. Jika norma dalam keluarga bertabrakan dengan nilai yang dibangun dalam lingkungan pekerjaan, maka perempuan tidak akan bisa mampu bekerja secara maksimal, begitu pula dalam tatanan nilai beragama perempuan juga dapat mensinergikan dengan norma keluarga yang menjadi tujuan dalam membangun sistem keluarga. Kumpulan nilai yang dimiliki perempuan dalam dirinya bukan sekedar kolektivitas nilai dan norma, harus di tata sedemikian rupa sehingga mampu berfungsi dalam sebuah hubungan yang 
Peran Ganda (Bekerja Sekaligus Ibu Rumah Tangga) Perempuan Muslimah...

harmonis dan berkolaborasi dengan sistem lainnya. Sebagai sistem keluarga, sistem kerja dan sistem agama dalam diri perempuan muslimah yang bekerja membutuhkan dukungan terhadap semua sistem yang melingkupinya, perempuan yang bekerja lebih memungkinkan menganut nilai dan norma dalam sistem agama yang membolehkan perempuan bekerja, atau menggunakan tatanan keluarga yang lebih moderat, mendukung partisipasi perempuan dalam ruang publik. Dukungan sistem nilai yang terkait dengan perempuan bekerja dalam pandangan agama Islam dapat diperoleh dari beberapa catatan sejarah perempuan-perempuan yang dekat dengan Rosullullah yang bekerja sebagai pedagang, seperti bagaimana istri beliau Khadijah sendiri adalah seorang pedangang perempuan yang kaya raya sukses dengan kerajaan bisnisnya. Inilah yang mampu mendorong tercapainya sistem yang harmonis dengan dukungan antara sistem nilai yang dibangun.

Sistem keluarga harus mampu memenuhi kebutuhan para aktornya dalam proporsi yang signifikan. Perempuan dalam keluarga harus mendapatkan kemanfaatan yang dibutuhkan perempuan, kalau dalam keluarga ia membutuhkan keamanan, maka keluarga harus memenuhinya. Perempuan harus dilindungan dalam naungan keluarga, jangan ada ancaman fisik maupun psikis dalam lingkungan kelurga, apabila ada maka fungsi keluarga yang dibutuhkan perempuan tidak terpenuhi. Jika tidak terpenuhi, maka peran yang miliki perempuan sebagai aktor dalam keluarga tidak terlaksana dengan baik. Partispasi yang memadai dari masing-masing aktor dalam keluarga muslim menciptakan sistem keluarga yang utuh dan harmonis. Mampu mengendalikan perilaku aktor yang berpotensi menganggu, perempuan secara memadai mengeluarkan potensinya yang bekerja serta bersedia menjadi ibu rumah tangga dalam perannya sebagai feminim ekspresif. Harapannya dengan fungsi ekspresifnya tersebut mampu mengendalikan konflik yang menimbulkan kekacauan. Peran bahasa dalam menciptakan suasana yang kondusif bagi sistem keluarga diperlukan untuk mengkomunikasikan bagaimana sistem nilai dapat dibangun sesuai harmonisasi sistem norma yang lainnya. Dengan bahasa pengertian dan definisi serta tuntutan dari nilai dan norma dapat ditekan, dimanipulasi dengan berbagai kondisi yang ada demi tercapainya sebuah keseimbangan dalam membangun sistem keluarga. Bahasa memainkan perenan penting dalam menjelaskan berbagai domain status dan peran yang melekat pada diri perempuan muslimah yang bekerja, agar peran ganda menjadi bagian yang terintegrasi dalam menjalankan fungsi.

\section{Kesimpulan}

Kajian perempuan dalam struktural fungsional memang terkesan basi dan cukup tidak menarik, karena masih menggunakan paradigma yang lama. Konsep pendekatan sistem yang masih sangat relevan jika orientasinya pada keseimbangan sistem. Ternyata teorinya yang terbaru dalam menggunakan penekatan sistem 
masih belum dapat maksimal, karena belum siapnya kesadaran yang dibangun antar aktor dalam sistem tersebut. Kesadaran dalam setiap anggota penyusun unsur elemen dalam sistem tersebut belum pada tahap pengorganisasian nilai dan norma namun masih pada tahap memaksakan meleburnya elemen dalam sistem dalam mencapai sebuah keseimbangan. Adapun alasan paling dapat diterima, jika perempuan dalam menjalankan peran ganda dalam keluarga adalah adanya sistem nilai yang kuat pada diri perempuan dalam membangun sistem keluaarga. Sistem nilai tersebut yang membuatnya mampu meleburkan persepsinya menjadi satu dengan sistem keluarga, bagi perempuan tidak ada muncul ego dan perasaan yang dinomor sekiankan asal keluarganya dapat bertahan dan berkesinambungan.

Prinsip dasar teori struktural fungsional adalah penerimaan peran dan status pada diri aktor demi tercapainya tujuan dari sistem yang dibangun. Peran dan status perempuan, meskipun ia sedang bekerja tidak dipermasalahkan sama sekali karena ada kendali norma agama yang menetralisir diri perempuan sehingga tidak menjadi pemicu konflik. Jika perempuan yang bekerja ini memeliki persepsi diri yang tinggi dan tidak bersedia ditempatkan dan wilayah domestik, maka bisa jadi sistem keluarganya akan terjadi pertikaian dan konflik.

Kesimpulannya adalah perempuan yang bekerja dapat ditempatkan dalam ranah domestik dibangun dengan sistem nilai agama dan kultur yang sangat kuat. Meskipun ini memberikan kesempatan terjadinya kekerasan rumahtangga yang tidak mampu diungkap oleh perempuan itu sendiri, sehingga membutuhkan pihak lain dalam mengatasi permasalahan tersebut. Keperpihakan dan kejelian dan mengungkap kasus yang terjadi pada perempuan dalam sistem yang sangat kuat, harus menjadi tujuan utamanya. Meskipun demikian, dalam diri perempuan juga lebih ditingkatkan lagi kesadarannya dalam memilih dan memutuskan kesetiaanya pada struktur keluarga, jika membuatnya bahagia secara lahir dan batin maka pertahankanlah, namun jika sebaliknya keluarlah dalam lingkungan yang tidak menguntungkan diri perempuan. Keberanian mengungkapkan diri menjadi hal paling penting sehingga pihak lain dapat membantunya dengan tetap mengutamakan perempuan sebagai pengambil semua keputusan atas apa yang dihadapinya.

\section{Daftar Pustaka}

Astutik, Juli, and Sugeng P Laksono. "Kekerasan Gender Dalam Berpacaran Di Kalangan Mahasiswa (Studi Kasus Di Malang) Gender Abuse on Dating of University Students (Case Study in Malang).” Jurnal Perempuan dan Anak 1, no. 1 (2015): 1-22.

Grbich, Carol. "New Approaches in Social Research." New Approaches in Social Research (2011).

Kolenda, Pauline. "Woman as Tribute, Woman as Flower: Images of 'Woman' in 
Peran Ganda (Bekerja Sekaligus Ibu Rumah Tangga) Perempuan Muslimah...

Weddings in North and South India." American Ethnologist 11, no. 1 (1984): 98-117.

Lazerwitz, Bernard. "Jewish-Christian Marriages and Conversions, 1971 and 1990." Sociology of Religion 56, no. 4 (1995): 433.

Marvasti, Amir B. Qualitative Research in Sociology. Edited by David Silverman.

London • Thousand Oaks • New Delh: SAGE Publications Ltd., 2004.

Maxwell, Joseph A., and L. Earle Reybold. "Qualitative Research.” In International

Encyclopedia of the Social \& Behavioral Sciences: Second Edition, 2015.

Narasatriangga, Abima, . Purwadi, and I Nyoman Dhana. "Dominasi Kultural Figur

Bunda Maria Dalam Ritual Semana Santa Pada Masyarakat Larantuka, Flores

Timur." Humanis (2018): 935.

Payne, Geoff, and Judy Payne. Key Concepts in Social Research. Trowbridge,Wilture: The Cromwell Press Ltd, 2004.

Poloma, Margaret. M. Sosiologi Kontemporer. Jakarta: Raja Grafindo Persada, 2010.

Ritzer, George and Smart, Barry. Hand Book Teori Sosial. Bandung: Nusa Media, 2014.

Ritzer, George, and Douglas J Goodman. Teori Sosiologi Modern. Jakarta: Prenada, 2005.

Rohmaniyah, Inayah. "Kontruksi Seksualitas Dan Relasi Kuasa Dalam Praktik Diskursif Pernikahan Dini." Musãwa Jurnal Studi Gender dan Islam 16, no. 1 (2018): 33.

Sev'er, Aysan, and Gökçeçiçek Yurdakul. "Culture of Honor, Culture of Change: A Feminist Analysis of Honor Killings in Rural Turkey." Violence Against Woman 7, no. 9 (September 30, 2001): 964-998. http://journals.sagepub.com/doi/10.1177/10778010122182866.

Soekanto, Soerjono. Tujuh Tokoh Sosiologi. Jakarta: Raja Grafindo Persada, 2011.

Tualeka, M. Wahid Nur. "Teori Konflik Sosiologi Klasik Dan Modern." Al-Hikmah (2017).

Zubaedah, Siti. "Mengurai Problematika Gender Dan Agama." JURNAL STUDI GENDER \& ANAK (2010). 